\title{
The effect of metabolic surgery on type 1 diabetes: meta-analysis
}

\author{
Abdulzahra Hussain'
}

${ }^{1}$ Doncaster and Bassetlaw Teaching Hospitals, DN2 5LT, Doncaster, UK

Correspondence to:

azahrahussain@yahoo.com

Received on Apr/22/2016

Accepted on Oct/10/2016

DOI: $10.20945 / 2359-3997000000021$

\begin{abstract}
Objective: Metabolic and bariatric surgery has a definite role in the management of obese patients with type 2 diabetes mellitus (T2DM). There is also evidence of such surgery improving the health of type 1 diabetic (T1DM) patients. The aim of this paper is to explore the effect of metabolic and bariatric surgery on T1DM. Materials and methods: A comprehensive search of PubMed and Google Scholar was performed to identify relevant papers reporting metabolic and bariatric surgery effects onT1DM. A statistical analysis is applied after data synthesis. A forest plot and Pearson correlation are then calculated. Results: Of the 567 papers that were identified, 558 articles did not fulfill the inclusion criteria and were therefore excluded. Nine studies involving 78 patients were selected for this metaanalysis. There was improvement in HBA1c $(p$ value $=0.40)$, insulin dose $(p$ value $=0.0001$ ) and BMI ( $p$ value $=0.00001$ ) after surgery. However, improvement in the HBA1c did not reach statistical significance. There was a weak correlation between postoperative insulin dose and $\mathrm{BMI}$ change after surgery $(r=-0.177)$. There was a negligible correlation between HBA1c and BMI change after operations $(r=-0.01)$. Conclusion: Current metabolic/bariatric surgery is improving T1DM in obese and morbidly obese patients. This is not exclusively related to excess weight loss (EWL) as previously thought. Therefore, there is a role for other factors, which are potential players to reproduce the same effect in nonobese T1DM patients. Arch Endocrinol Metab. 2018;62(2):172-8
\end{abstract}

Keywords

Bariatric surgery; metabolic surgery; type 1 diabetes mellitus; type 2 diabetes mellitus; HBA1c; insulin; body mass index

\section{INTRODUCTION}

$\mathrm{G}$ astrointestinal surgery has excellent but variable I outcomes on the glycemic control of diabetic patients depending on the type of surgery. The first report of gastrointestinal surgery ameliorating T2DM was reported by Friedman and cols. in 1955 (1), though its effect on TIDM was not recognized until recently when Czupryniak and cols. reported the first observation of TIDM improvement in a severely obese patient who underwent gastric bypass in 2004 (2). Hussain and cols. suggested the potential benefit of bariatric surgery for TIDM in 2009 (3), followed by Czupryniak and cols.'s case studies involving three patients in 2010 (4). Since then, several observational studies have reported changes in insulin requirement, HBAlc and BMI following different types of bariatric/metabolic surgery.

American Diabetic Association (ADA) and National Institute for Health and Care Excellence (NICE) guidelines have restricted the diagnosis of TIDM to situations in which the body does not produce insulin (5) or the destruction of insulin-producing beta cells in the pancreatic islets of Langerhans causes absolute insulin deficiency (6). This clear definition should avoid confusion in reporting insulin-dependent diabetic patients after bariatric/metabolic surgery, which could fall under either TIDM (when there is no insulin production) or T2DM (when insulin is produced but is not a sufficient amount for body requirements, or there is insulin resistance).

The metabolic effect of bariatric/metabolic surgery on TIDM has elicited significant interest because of the already-proven benefits on T2DM and the potential production of similar results for TIDM, which forms $10 \%$ of diabetic load (7-10). As there is no insulin production by pancreatic beta cells, the mechanisms of improving TIDM following metabolic/bariatric surgery are expected to be related to body mass index (BMI) change, reduction of insulin resistance, satiety/ dietary change and possible neuroendocrine/hormonal or incretins influence. The aim of this paper is to explore current evidence regarding the effect of metabolic surgery on TIDM.

\section{MATERIALS AND METHODS}

The protocol of Preferred Reporting Items for Systematic Review and Meta-Analysis (PRISMA) is used 
(Figure 1). Inclusion and exclusion criteria: All English literature reporting bariatric and metabolic surgery on TIDM patients (hyperglycemia, C-peptide negative and anti-glutamic acid carboxylase [GAC] antibodies positive) were included. The studies that reported less than three patients were excluded.

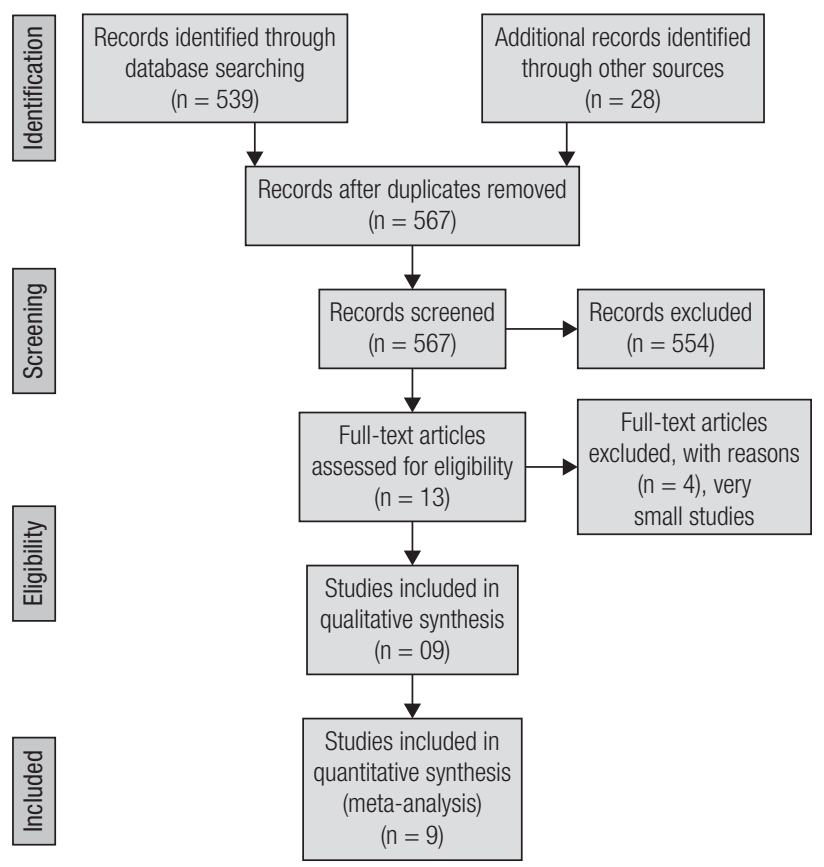

Source: Moher D, Liberati A, Tetzlaff J, Altman DG; The PRISMA Group (2009). Preferred Reporting Items for Systemic Reviews and Meta-Analyses: The PRISMA Statement. PLoS Med. 2009;6(7):e1000097.

Figure 1. Flow diagram.

\section{Quality of the data}

An assessment of the studies according to the NewcastleOttawa scoring system was performed (Table 1 ).

The data were reviewed and entered into the fields of Microsoft Excel. The data consisted of the following: sample size, authors, year of publication, HBAlc, insulin

Table 1. Newcastle-Ottawa assessment of the quality of data

\begin{tabular}{|c|c|c|c|}
\hline Studies & Selection & Comparability & Outcome \\
\hline Blanco and cols. (2014) & 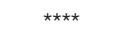 & * & ** \\
\hline Brethauer and cols. (2014) & $\star \star \star$ & & ** \\
\hline Czupryniak and cols. (2010) & *** & & ** \\
\hline Maraka and cols. (2015) & 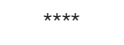 & * & ** \\
\hline Middelbeek and cols. (2015) & *** & & ** \\
\hline Raab and cols. (2013) & *** & & ** \\
\hline Robert and cols. (2015) & $* * * *$ & * & ** \\
\hline Lannoo and cols. (2014) & 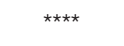 & & ** \\
\hline Mendez and cols. (2010) & *** & & $\star \star$ \\
\hline
\end{tabular}

dose, BMI before and after the surgery and follow-up duration. All the studies were observational research, and no clinical trials were to have been performed for the studies to be included. Three of them were comparative protocols that included a T2DM arm. Only TIDM data were selected. Some of the studies lacked the calculation of standard deviation (SD), which is an important requirement for conducting the forest plot calculation. The SD of each study was calculated from the number of subjects, the largest and smallest value and the $95 \%$ confidence interval of 3.92 . Some of the studies were lacking a mean of the specific data. Therefore, a calculation of the mean was performed. The patients' follow-ups varied, even within a single study. Some studies provided follow-up at 6 months, 1 year, 2 years, 3 years, 4 years or 5 years. The included data were taken from the longest follow-up to give more power to the results. Few studies reported insulin dose per kilogram $(\mathrm{kg})$ of body weight/day, while the majority quoted total units/day. It was not possible to know the total units/day for these few studies (Table 2), so the reported unit $/ \mathrm{kg} /$ day is used for analysis.

\section{Data synthesis}

Data synthesis was completed and is shown in Table 2. Further calculation of change in the mean of three variables is depicted in Table 3. The forest plot was performed for HBAlc, Insulin dose and BMI changes after surgery (Figures 2, 3 and 4). Pearson correlation statistics were applied, and the results are shown in Table 4.

\section{Statistical analysis}

Review Manager software was used (Review Manager 5.3, version: 5.3.5). A 95\% confidence interval (CI) and $\mathrm{p}<0.05$ limit was taken as significant. An odd ratio $(\mathrm{OR})$, variance, standard errors and deviations were applied, and a forest plot for depicting the final results of each parameter was constructed. Different parameters such as age, insulin requirements, HBAlc, BMI and duration of diabetes were included in the final analysis. Further analysis was conducted to show the relations and degree of correlation between these 5 parameters. The correlation tests were performed using Excel (Microsoft 365, 2015) and also R software from the $\mathrm{R}$ Foundation for Statistical Computing (http://www.R-project.org). The test of normality was conducted for all data using Jarque-Bera and AndersonDarling normality tests. The correlation coefficient (r) was calculated using the following equation: $R$ 
Calculation, $\mathrm{r}=\Sigma\left(\left(\mathrm{X}-\mathrm{M}_{\mathrm{y}}\right)\left(\mathrm{Y}-\mathrm{M}_{\mathrm{x}}\right)\right) / \sqrt{ }\left(\left(\mathrm{SS}_{\mathrm{x}}\right)\left(\mathrm{SS}_{\mathrm{y}}\right)\right)$.

Data synthesis was performed, and statistical analysis and it was calculated using $\mathrm{SD}=\sqrt{\mathrm{Nx}}(\mathrm{X}-\mathrm{x}) / 3.92$ and a confidence interval of $95 \%$ (http://handbook. cochrane.org).

Table 2. Main data, the standard deviation is calculated using the formula $S D=\sqrt{n} x[X-x)^{2} / 3.92, n=$ number of subjects, $X=$ upper limit value, $x=$ lower limit, $3.92=95 \%$ confidence interval, $\mathrm{Cl}$. The values in the table represent the mean of the data plus SD when available. For insulin requirements, some data depicted as $I U / \mathrm{kg} /$ day rather than total unit/day

\begin{tabular}{|c|c|c|c|c|c|c|c|c|}
\hline & Year & $\begin{array}{l}\text { Age (mean) } \\
\text { years }\end{array}$ & 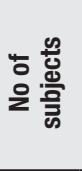 & $\begin{array}{c}\text { HBA1c before/after } \\
\text { surgery }\end{array}$ & $\begin{array}{c}\text { Insulin } \\
\text { requirements } \\
\text { before/after } \\
\text { surgery IU/day } \\
\text { (u/k/day) }\end{array}$ & $\begin{array}{l}\text { BMI kg/m² before/ } \\
\text { after surgery }\end{array}$ & $\begin{array}{c}\text { Duration } \\
\text { of T1DM in } \\
\text { years }\end{array}$ & $\begin{array}{l}\text { Follow up } \\
\text { (month = m) }\end{array}$ \\
\hline Czupryniak and cols. & 2010 & $22 \pm 6$ & 3 & $\begin{array}{l}10.13 \pm 1.32 / \\
09.00 \pm 0.73\end{array}$ & $\begin{array}{c}94 \pm 6.3 / \\
47.6 \pm 6.42\end{array}$ & $\begin{array}{l}42.2 \pm 2.39 / \\
33.5 \pm 2.65\end{array}$ & 11.60 & $5-8$ years \\
\hline Raab and cols. & 2013 & 43 & 6 & $\begin{array}{c}8.18 \pm 2.17 / \\
6.95 \pm 1.4\end{array}$ & $\begin{array}{c}104.16 \pm 11.59 / \\
36.75 \pm 7.72\end{array}$ & $\begin{array}{l}41.75 \pm 5.89 / \\
27.82 \pm 2.37\end{array}$ & 17.16 & 1 year \\
\hline Robert and cols. & 2015 & $39.2 \pm 5.3$ & 10 & $\begin{array}{l}7.5 \pm 1.9 / \\
7.1 \pm 0.9\end{array}$ & $\begin{array}{l}1.09 \pm 0.7 / \\
0.44 \pm 0.24\end{array}$ & $\begin{array}{l}46.9 \pm 6.3 / \\
30.34 \pm 6.3\end{array}$ & $\begin{array}{c}23.1 \pm \\
11.8\end{array}$ & 4.5 years \\
\hline Maraka and cols. & 2015 & $50.6 \pm 8.9$ & 7 & $\begin{array}{l}8.2 \pm 1.6 / \\
7.8 \pm 0.9\end{array}$ & $\begin{array}{l}75.15 \pm 6.4 / \\
55.45 \pm 5.17\end{array}$ & $\begin{array}{c}44.3 \pm 8.0 / \\
31.2 \pm 9.9\end{array}$ & $20.6 \pm 11.4$ & 2 years \\
\hline Blanco and cols. & 2014 & $38.2 \pm 13.3$ & 7 & $\begin{array}{l}8.3 \pm 1.2- \\
8.2 \pm 0.9\end{array}$ & $\begin{array}{l}0.61 \pm 0.17 / \\
0.62 \pm 0.12\end{array}$ & $\begin{array}{l}39.4 \pm 2.2 / \\
27.3 \pm 2.2\end{array}$ & $27.3 \pm 2.2$ & 2 years \\
\hline Middelbeek and cols. & 2015 & $39.6 \pm 8.4$ & 10 & $\begin{array}{l}8.1 \pm 1.3 / \\
9.8 \pm 1.9\end{array}$ & $\begin{array}{l}53.0 \pm 29.7 / \\
31.1 \pm 22.8\end{array}$ & $\begin{array}{l}43.5 \pm 7.5 / \\
33.8 \pm 7.5\end{array}$ & $\begin{array}{c}24.6 \pm \\
10.1\end{array}$ & 5 years \\
\hline Brethauer and cols. & 2014 & $45.6 \pm 10.9$ & 10 & $\begin{array}{l}10 \pm 1.6 / \\
8.9 \pm 1.1\end{array}$ & $\begin{array}{c}0.74 \pm 0.32 / \\
0.40 \pm 0\end{array}$ & $\begin{array}{l}41.6 \pm 3.9 / \\
30.5 \pm 5.9\end{array}$ & 22 & $36.8 \pm 32.3(\mathrm{~m})$ \\
\hline Lannoo and cols. & 2014 & $40.3 \pm 8.5$ & 22 & $\begin{array}{l}8.4 \pm 2.34 / \\
8.2 \pm 2.11\end{array}$ & $\begin{array}{c}92.5 \pm 13.81 / \\
48.0 \pm 11.36\end{array}$ & $\begin{array}{l}39.7 \pm 5.34 / \\
31.4 \pm 2.86\end{array}$ & $25.3 \pm 8.9$ & $\begin{array}{l}14.3 \pm 10.1 / \\
37.8 \pm 29.7\end{array}$ \\
\hline Mendez and cols. & 2010 & 42.3 & 3 & $\begin{array}{l}7.96 \pm 0.67 / \\
8.03 \pm 0.99\end{array}$ & $\begin{array}{c}99.23 \pm 9.36 / \\
42.9 \pm 3.10\end{array}$ & $\begin{array}{l}45.9 \pm 3.11 / \\
29.4 \pm 1.77\end{array}$ & 25 & 1 year \\
\hline
\end{tabular}

Table 3. Mean change in 3 variables BMI, HBA1c and insulin requirement, mean duration of T1DM (years) and age (years) are fixed

\begin{tabular}{lcccc}
\hline HBA1C & Insulin requirement & Duration of T1DM & BMI & AGE \\
\hline 1.13 & 46.40 & 11.60 & 08.70 & 22.0 \\
1.23 & 67.41 & 17.16 & 13.95 & 43.0 \\
0.40 & 00.65 & 23.10 & 16.56 & 39.2 \\
0.40 & 19.70 & 20.60 & 13.10 & 50.6 \\
0.10 & 00.01 & 27.30 & 12.10 & 38.2 \\
-1.70 & 21.90 & 24.60 & 09.70 & 39.6 \\
0.10 & 00.34 & 22.00 & 11.10 & 45.6 \\
-0.07 & 56.33 & 25.30 & 08.30 & 40.3 \\
\hline
\end{tabular}

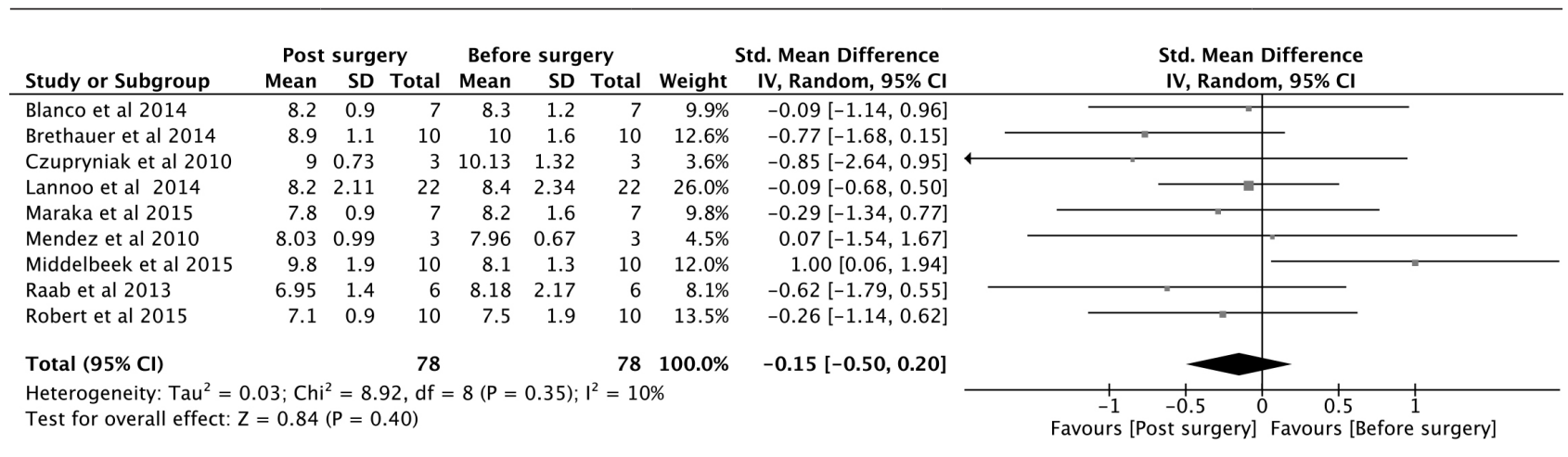

Figure 2. Forest plot, HBA1c. 


\begin{tabular}{|c|c|c|c|c|c|c|c|c|c|c|c|}
\hline \multirow[b]{2}{*}{ Study or Subgroup } & \multicolumn{3}{|c|}{ Post surgery } & \multicolumn{3}{|c|}{ Before surgery } & \multicolumn{2}{|c|}{ Std. Mean Difference } & \multirow{2}{*}{\multicolumn{3}{|c|}{$\begin{array}{l}\text { Std. Mean Difference } \\
\text { IV, Random, } 95 \% \mathrm{CI}\end{array}$}} \\
\hline & Mean & SD & Total & Mean & SD & Total & Weight & IV, Random, 95\% Cl & & & \\
\hline Middelbeek et al 2015 & 31.1 & 22.8 & 10 & 53 & 29.7 & 10 & $15.3 \%$ & $-0.79[-1.71,0.13]$ & & & \\
\hline Lannoo et al 2014 & 48 & 11.36 & 22 & 92.5 & 13.81 & 22 & $15.1 \%$ & $-3.46[-4.42,-2.50]$ & & & \\
\hline Robert et al 2015 & 0.44 & 0.24 & 10 & 1.09 & 0.7 & 10 & $15.1 \%$ & $-1.19[-2.16,-0.22]$ & & & \\
\hline Brethauer et al 2014 & 0.4 & 0.15 & 10 & 0.74 & 0.32 & 10 & $15.0 \%$ & $-1.30[-2.29,-0.32]$ & - & & \\
\hline Blanco et al 2014 & 0.62 & 0.12 & 7 & 0.61 & 0.17 & 7 & $14.8 \%$ & $0.06[-0.98,1.11]$ & & 一 & \\
\hline Maraka et al 2015 & 55.45 & 5.17 & 7 & 75.15 & 6.4 & 7 & $12.1 \%$ & $-3.17[-4.91,-1.43]$ & & & \\
\hline Raab et al 2013 & 36.75 & 7.72 & 6 & 104.16 & 11.59 & 6 & $6.9 \%$ & $-6.32[-9.60,-3.03]$ & & & \\
\hline Czupryniak et al 2010 & 47.6 & 6.42 & 3 & 94 & 6.3 & 3 & $3.0 \%$ & $-5.84[-11.69,0.02]$ & & & \\
\hline Total $(95 \% \mathrm{Cl})$ & & & 78 & & & 78 & $100.0 \%$ & $-2.17[-3.30,-1.05]$ & & & \\
\hline $\begin{array}{l}\text { Heterogeneity: } \mathrm{Tau}^{2}= \\
\text { Test for overall effect: }\end{array}$ & $\begin{array}{l}93 ; \mathrm{Chi}^{2} \\
=3.79\end{array}$ & $\begin{array}{l}=43.3 \\
P=0.0\end{array}$ & $\begin{array}{l}31, \mathrm{df}= \\
001)\end{array}$ & $8(P<0$ & $.00001)$ & $; 1^{2}=8$ & & & $\begin{array}{lc}-10 & -5 \\
& \text { Favours [post surgery] }\end{array}$ & Favours [be & $\begin{array}{lr}1 & 1 \\
5 & 10 \\
\text { efore surgery] }\end{array}$ \\
\hline
\end{tabular}

Figure 3. Forest plot, insulin.

\begin{tabular}{|c|c|c|c|c|c|c|c|c|c|c|c|c|}
\hline \multirow[b]{2}{*}{ Study or Subgroup } & \multicolumn{3}{|c|}{ Post surgery } & \multicolumn{3}{|c|}{ Before surgery } & \multicolumn{2}{|c|}{ Std. Mean Difference } & \multirow{2}{*}{\multicolumn{4}{|c|}{$\begin{array}{c}\text { Std. Mean Difference } \\
\text { IV, Random, } 95 \% \mathrm{CI}\end{array}$}} \\
\hline & Mean & SD & Total & Mean & SD & Total & Weight & IV, Random, 95\% Cl & & & & \\
\hline Blanco et al 2014 & 27.3 & 2.2 & 7 & 39.4 & 2.2 & 7 & $4.9 \%$ & $-5.15[-7.63,-2.67]$ & & & & \\
\hline Brethauer et al 2014 & 30.5 & 5.9 & 10 & 41.6 & 3.9 & 10 & $14.9 \%$ & $-2.13[-3.27,-0.98]$ & & & & \\
\hline Czupryniak et al 2010 & 33.5 & 2.65 & 3 & 42.2 & 2.39 & 3 & $3.3 \%$ & $-2.76[-5.87,0.35]$ & & & & \\
\hline Lannoo et al 2014 & 31.4 & 2.8 & 22 & 39.7 & 5.34 & 22 & $22.1 \%$ & $-1.91[-2.64,-1.19]$ & & -- & & \\
\hline Maraka et al 2015 & 31.2 & 9.9 & 7 & 44.3 & 8 & 7 & $14.1 \%$ & $-1.36[-2.57,-0.16]$ & & & & \\
\hline Mendez et al 2010 & 29.4 & 1.77 & 3 & 45.9 & 3.11 & 3 & $1.2 \%$ & $-5.22[-10.50,0.07]$ & & & & \\
\hline Middelbeek et al 2015 & 33.8 & 7.5 & 10 & 43.5 & 7.5 & 10 & $17.5 \%$ & $-1.24[-2.21,-0.26]$ & & —- & & \\
\hline Raab et al 2013 & 27.82 & 2.37 & 6 & 41.75 & 5.8 & 6 & $8.2 \%$ & $-2.90[-4.72,-1.09]$ & & & & \\
\hline Robert et al 2015 & 30.34 & 6.3 & 10 & 46.9 & 6.3 & 10 & $13.7 \%$ & $-2.52[-3.75,-1.28]$ & & & & \\
\hline Total $(95 \% \mathrm{Cl})$ & & & 78 & & & 78 & $100.0 \%$ & $-2.14[-2.74,-1.54]$ & & & & \\
\hline $\begin{array}{l}\text { Heterogeneity: } \mathrm{Tau}^{2}= \\
\text { Test for overall effect: }\end{array}$ & $\begin{array}{l}28 ; \mathrm{Chi}^{2} \\
=7.01\end{array}$ & $\begin{array}{l}2=1 \\
(P<C\end{array}$ & $\begin{array}{l}.98, \mathrm{df} \\
.00001\end{array}$ & $=8(\mathrm{P}$ & 0.11 & $1^{2}=3$ & & & -10 & $\begin{array}{l}1 \\
-5 \\
\text { rs [post surgery] }\end{array}$ & Favours [bef & $\begin{array}{cc}1 & 1 \\
5 & 10 \\
\text { fore surgery] }\end{array}$ \\
\hline
\end{tabular}

Figure 4. Forest plot, body mass index change after surgery.

Table 4. Pearson correlation for 2 constant (age and duration of T1DM) and 3 variable post operative parameters (insulin requirements, HBA1c change and BMI change) combination. Significant moderate correlation between any two parameters is depicted in grey color $(0 .-0.39=$ weak, $0.4-0.59$ moderate, $0.6-0.79=$ strong, $0.8-1.0=$ very strong, Evans guide 1996)

\begin{tabular}{lccccc}
\hline & Age & Duration of T1DM & Insulin requirement & HBA1c & $\begin{array}{c}\text { BMI change after } \\
\text { surgery }\end{array}$ \\
\hline Age & ---- & 0.509 & -0.208 & -0.220 & 0.405 \\
Duration of T1DM & 0.509 & ---- & -0.418 & -0.513 & 0.204 \\
Insulin requirement & -0.208 & -0.418 & ----- & 0.475 & -0.177 \\
HBA1C & -0.210 & -0.513 & 0.475 & ---- & -0.010 \\
BMl & 0.405 & 0.204 & -0.177 & -0.010 & --- \\
\hline
\end{tabular}

\section{RESULTS}

\section{Type of bariatric/metabolic procedure}

The included patients underwent laparoscopic adjustable gastric band (LAGB), 2 patients (2.5\%); vertical sleeve gastrectomy (VSG), 11 patients (14\%); laparoscopic Roux-en Y gastric bypass (LRYGB), 52 patients (67\%); bilio-pancreatic diversion (BPD) 7 patients (9\%); or bilio-pancreatic diversion plus duodenal switch (BPD-DS), 3 patients (3.8\%). Except gastric bypass, all other operations included a small number of patients who fell short in terms of providing statistical power, and no subgroup analysis was conducted. Therefore, the outcomes were those of the 5 procedures.

\section{HBA1c}

HBAlc showed improvement after surgery; however, this improvement did not reach statistical significance, as the $\mathrm{p}$ value was 0.40 (Figure 2). HBAlc was moderately correlated with the duration of TIDM $(\mathrm{r}=-0.513)$ and insulin requirement $(\mathrm{r}=0.475)$. HBAlc showed little or no correlation with BMI $(\mathrm{r}=$ $0.01)$ but a stronger correlation with age $(\mathrm{r}=-022)$.

\section{Insulin requirement}

Insulin requirement was significantly reduced after surgery, with $\mathrm{p}$ value $=0.00001$ (Figure 3$)$. It was moderately correlated with HBAlc, as expected $(\mathrm{r}=0.475)$, and with duration of TIDM $(\mathrm{r}=-0.418)$. More importantly, it was weakly correlated with BMI 
change after surgery $(\mathrm{r}=-.0177)$ and also with age $(\mathrm{r}=$ -0.208 ) (Figures 2 and 4 ).

\section{Duration of the diabetes}

The mean duration of TIDM was 9.6 to 34.9 years, and it was correlated with age $(r=0.509)$. Duration of TIDM was moderately correlated with post-surgery insulin requirements and $\mathrm{HBAlc}$ and weakly correlated with BMI $(\mathrm{r}=-0.418,-0.513,0.204$, respectively $)$ (Table 4).

\section{Excess weight loss}

All studies showed an acceptable amount of weight loss ranging from 8.3 to 16.56 kilograms $/ \mathrm{m}^{2}$. BMI change after surgery was weakly correlated with duration of diabetes, HBAlc and insulin requirement; however, it had significant correlation with age $(\mathrm{r}=0.405)$ (Table 4$)$.

\section{Age group}

The age group ranged from 16-65 years with mean of 40.16 years. There was a weak negative correlation with postoperative insulin dose and HBAlc ( $\mathrm{r}=$ $-0.205,-0.21$, respectively). Age group was moderately correlated with duration of TIDM and BMI $(r=0.509$, 0.405 , respectively).

\section{DISCUSSION}

HBAlc and postoperative insulin dose are important parameters to assess glycemic control in T1DM patients following metabolic surgery. All but 2 studies (Middelbeek and cols. 2015 and Mendez and cols. 2010) showed a variable degree of improvement in HBAlc, although it did not reach statistical significance (4,11-18) (Figure 2). However, the insulin dose is significantly reduced following surgery, and it is moderately correlated with duration of TIDM and HBAlc level. This meta-analysis showed a weak correlation among postoperative HBAlc, insulin requirement and postoperative BMI loss. Therefore, the improvement in the HBAlc and insulin dose shortly after surgery is not entirely related to weight loss. The largest study of Lannoo and cols. (11) concluded that the insulin-sparing effect is probably related to insulin sensitivity following weight loss. However, according to this meta-analysis, the insulin-sparing effect is only weakly correlated with weight loss. We have to look beyond the anatomical configurations and physical effects of these procedures and explore the complex metabolic pathway of glucose homeostasis.

Incretins play a role in glucose regulation by reducing glucagon and food intake and increasing satiety (19). A recent review study highlighted the established roles of gut hormones in regard to diabetes (20). Metabolic and bariatric surgery may possibly produce insulin dose reduction and improve HBAlc through an incretinsrelated mechanism, but this does not exclude other potential factors that control glucose metabolism (21). The change in the nutrient flux could affect the balance of gut hormones (including hypothetical anti-incretins), and the change in hormone milieu might be responsible for changes in insulin sensitivity (22).

In their study, Kempf and cols. showed a rapid decrease of insulin requirement and an improvement in HBAlc in T2DM as a result of meal modification even before substantial weight loss occurred (23). Glycogenolysis, gluconeogenesis, carbohydrate intake and the modified response of the metabolism to postmetabolic/bariatric surgery in regard to anatomical, neuroendocrine and satiety changes are the primary cofactors for net glucose production. The interaction of these complex mechanisms produces the final blood glucose level, whether it is normal, hypoglycemic or hyperglycemic.

Following procedures such as gastric bypass, some T2DM patients develop hypoglycemia. The incidence of symptomatic hypoglycemia is less than $1 \%$ (24). However, asymptomatic post-bariatric/metabolic surgery hypoglycemia could reach $30 \%$ (25). In these patients, we possibly overdoing metabolic correction. On the other hand, in TIDM, the beta-cell influence on glucose homeostasis is absent, and therefore the entire set of regulatory mechanisms consists of the complex interactions among the gastrointestinal tract (GIT), liver, brain, adipose tissue, blood cells, muscles and kidneys. This results in the regulation of glucose entry into the circulation being influenced by additional factors such as hormones, the sympathetic nervous system and substrates (i.e., free fatty acid concentrations and availability of gluconeogenic precursors) (26).

The question regarding how to adjust the anatomical change of the gastrointestinal tract as a result of metabolic surgery and the inherent complex interactions among these systems to optimize the glucose level in T1DM is very difficult based on the current level of knowledge surrounding metabolic/bariatric surgery. Every single centimeter of the GIT is a complex unit, and any change 
caused by metabolic and bariatric surgery will result in a comparative impact to the glucose homeostasis. Such changes will never result in total glycemic control, and the patient will still need an insulin replacement, regardless of the preoperative insulin dose. Currently, we do not entirely know what each part of the GIT produces (except some factors such as incretins, PYY hormones and ghrelins), and we are still a far way from being in a position to perfect metabolic/bariatric surgery to produce the maximum benefit for TIDM patients. The interaction between diet and GIT has been a very important focus of interest. A very low calorie diet (VLCD) was found to produce similar effects to gastric bypass in terms of insulin sensitivity and beta-cell function improvement in T2DM (27). As diabetes is a spectrum of disease, the same effect could therefore be produced in TIDM. To date, no study has examined the potential effect of VLCD on TIDM. Bile acids are recognized effectors on the regulation of glucose and lipid metabolism through the FXR and TGR5 receptors (28). There is evidence that the alteration of bile acids following bariatric surgery improves insulin responsiveness and lowers fasting glucose in animal models (29). A similar effect may be reproduced in humans, and it may be a mechanism through which to explain the effect of metabolic surgery on diabetic patients.

There is no direct link between gut microbiota and improvement in glucose homeostasis following bariatric surgery. Gut microbiota does, however, have a direct effect on weight. An interesting study showed that transferring microbiota from an obese subject to a lean subject resulted in weight gain (30). The hepatocytes orchestrate the regulatory mechanisms of bile acids, microbiota and metabolome to affect glucose and lipid metabolism (31). Future research may prove the existence of a link between microbiota and beta-cell function.

\section{Limitations of the study}

This meta-analysis included 9 studies with some degree of heterogeneity that ranged from $10-82 \%$. The studies are relatively small, with the largest reporting 22 patients. The patient follow-ups are different, as some studies reported 1 year, whereas others reported up to 5 years. The outcomes, especially HBAlc, may be creeping up with longer follow-up, as shown by Middelbeek and cols.'s 2015 study (12), and the current conclusion regarding HBAlc is represented by the mean follow- ups in these studies. Some studies included women only (like Middlbeek and cols. 2015), whereas others reported women as the majority. This would raise a question regarding the actual representation of the obese TIDM population; nevertheless, the studies are shedding a light on such patients who require extra help with glycemic control after having exhausted current nonsurgical methods.

\section{CONCLUSION}

Current metabolic/bariatric surgery is reducing postoperative insulin requirement and marginally improving HBAlc in obese and morbidly obese type 1 diabetic patients. This is not exclusively related to the EWL as previously thought. Therefore, there is a role for other factors, which are potential players to reproduce the same effect in nonobese TIDM patients. Further long-term studies are required to assess the real benefit of metabolic surgery for TIDM patients.

Acknowledgments: none.

Disclosure: no potential conflict of interest relevant to this article was reported.

\section{REFERENCES}

1. Friedman MN, Sancetta AJ, Magovern GJ. The amelioration of diabetes mellitus following subtotal gastrectomy. Surg Gynecol Obstet. 1955;100(2):201-4.

2. Czupryniak L, Strzelczyk J, Cypryk K, Pawlowski M, Szymanski D, Lewinski A, et al. Gastric bypass surgery in severely obese type 1 diabetic patients. Diabetes Care. 2004;27(10):2561-2.

3. Hussain A, Mahmood H, El-Hasani S. Can Roux-en-Y gastric bypass provide a lifelong solution for diabetes mellitus? Can J Surg. 2009;52(6):E269-75.

4. Czupryniak L, Wiszniewski M, Szymański D, Pawłowski M, Loba J, Strzelczyk J. Long-term results of gastric bypass surgery in morbidly obese type 1 diabetes patients. Obes Surg. 2010;20(4):506-8.

5. American Diabetic Association ADA. Available from: http://www. diabetes.org. Access on: Oct. 2, 2015.

6. National Institute for Health and Care Excellence (NICE). Available from: http://cks.nice.org.uk. Access on: Oct. 2, 2015.

7. Sieber P, Gass M2 Kern B, Peters T, Slawik M, Peterli R. Five-year results of laparoscopic sleeve gastrectomy. Surg Obes Relat Dis. 2014;10(2):243-9.

8. Brethauer SA, Aminian A, Romero-Talamás H, Batayyah E, Mackey J, Kennedy L, et al. Can diabetes be surgically cured? Longterm metabolic effects of bariatric surgery in obese patients with type 2 diabetes mellitus. Ann Surg. 2013 Oct;258(4):628-36.

9. Keating C, Neovius M, Sjöholm K, Peltonen M, Narbro K, Eriksson JK, et al. Health-care costs over 15 years after bariatric surgery for patients with different baseline glucose status: results from the Swedish Obese Subjects study. Lancet Diabetes Endocrinol. 2015;3(11):855-65 
10. Sjöström L, Peltonen M, Jacobson P, Ahlin S, Andersson-Assarsson J, Anveden $\AA$, et al. Association of bariatric surgery with longterm remission of type 2 diabetes and with microvascular and macrovascular complications. JAMA. 2014;311(22):2297-304.

11. Lannoo M, Dillemans $B$, Van Nieuwenhove $Y$, Fieuws $S$, Mathieu C, Gillard $\mathrm{P}$, et al. Bariatric surgery induces weight loss but does not improve glycemic control in patients with type 1 diabetes. Diabetes Care. 2014;37(8):e173-4.

12. Middelbeek RJ, James-Todd T, Cavallerano JD, Schlossman DK, Patti ME, Brown FM. Gastric Bypass Surgery in Severely Obese Women With Type 1 Diabetes: Anthropometric and Cardiometabolic Effects at 1 and 5 Years Postsurgery. Diabetes Care. 2015;38(7):e104-5.

13. Mendez CE, Tanenberg RJ, Pories W.. Outcomes of Roux-en-Y gastric bypass surgery for severely obese patients with type 1 diabetes: a case series report. Diabetes Metab Syndr Obes. 2010;3:281-3.

14. Robert M, Belanger P, Hould FS, Marceau S, Tchernof A, Biertho L. Should metabolic surgery be offered in morbidly obese patients with type I diabetes? Surg Obes Relat Dis. 2015;11(4):798-805.

15. Raab H, Weiner RA, Frenken M, Rett K, Weiner S. Obesity and metabolic surgery in type 1 diabetes mellitus. Nutr Hosp. 2013 Mar;28 Suppl 2:31-4.

16. Maraka S, Kudva YC, Kellogg TA, Collazo-Clavell ML, Mundi MS. Bariatric surgery and diabetes: Implications of type 1 versus insulin-requiring type 2. Obesity (Silver Spring). 2015;23(3):552-7.

17. Blanco J, Jiménez A, Casamitjana R, Flores L, Lacy A, Conget I, et al. Relevance of beta-cell function for improved glycemic control after gastric bypass surgery. Surg Obes Relat Dis. 2014 ;10:9-13.

18. Brethauer SA, Aminian A, Rosenthal RJ, Kirwan JP, Kashyap SR, Schauer PR. Bariatric surgery improves the metabolic profile of morbidly obese patients with type 1 diabetes. Diabetes Care. 2014;37(3):e51-2.

19. Kim W, Egan JM. The role of incretins in glucose homeostasis and diabetes treatment. Pharmacol Rev. 2008;60(4):470-512.

20. Singh AK, Singh R, Kota SK. Bariatric surgery and diabetes remission: Who would have thought it? Indian J Endocrinol Metab. 2015;19(5):563-76.
21. Middelbeek RJ, James-Todd T, Patti ME, Brown FM. Short-term insulin requirements following gastric bypass surgery in severely obese women with type 1 diabetes. Obes Surg. 2014;24(9):1442-6.

22. Rubino F, R'bibo SL, del Genio F, Mazumdar M, McGrawTE. Metabolic surgery: the role of the gastrointestinal tract in diabetes mellitus. Nat Rev Endocrinol. 2010;6(2):102-9.

23. Kempf K, Schloot NC, Gärtner B, Keil R, Schadewaldt P, Martin $\mathrm{S}$. Meal replacement reduces insulin requirement, $\mathrm{HbA} 1 \mathrm{c}$ and weight long-term in type 2 diabetes patients with $>100 \mathrm{U}$ insulin per day. J Hum Nutr Diet. 2014;27 Suppl 2:21-7.

24. Foster-Schubert KE. Hypoglycemia complicating bariatric surgery: incidence and mechanisms. Curr Opin Endocrinol Diabetes Obes. 2011;18(2):129-33.

25. Goldfine AB, Mun EC, Devine E, Bernier R, Baz-Hecht M, Jones $D B$, et al. Patients with neuroglycopenia after gastric bypass surgery have exaggerated incretin and insulin secretory responses to a mixed meal. J Clin Endocrinol Metab. 2007;92(12):4678-85.

26. Shrayyef MZ, Gerich JE. Normal Glucose Homeostasis. Principles of Diabetes Mellitus. 2010; p. 19-35.

27. Jackness C, Karmally W, Febres G, Conwell IM, Ahmed L, Bessler $M$, et al. Very low-calorie diet mimics the early beneficial effect of

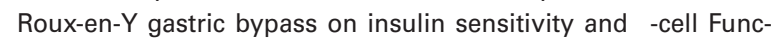
tion in type 2 diabetic patients. Diabetes. 2013;62(9):3027-32.

28. Albaugh VL, Flynn CR, Tamboli RA, Abumrad NN. Recent advances in metabolic and bariatric surgery. F1000Res. 2016 May 24;5. pii: F1000 Faculty Rev-978.

29. Goncalves D, Barataud A, De Vadder F, Vinera J, Zitoun C, Duchampt $A$, et al. Bile Routing Modification Reproduces Key Features of Gastric Bypass in Rat. Ann Surg. 2015;262(6):1006-15.

30. Bäckhed F, Ding H, Wang T, Hooper LV, Koh GY, Nagy A, et al. The gut microbiota as an environmental factor that regulates fat storage. Proc Natl Acad Sci U S A. 2004;101(44):15718-23.

31. Duparc T, Plovier H, Marrachelli VG, Van Hul M, Essaghir A, Ståhlman M, et al. Hepatocyte MyD88 affects bile acids, gut microbiota and metabolome contributing to regulate glucose and lipid metabolism. Gut. 2017;66(4):620-32. 